\title{
PENGARUH MODEL PEMBELAJARAN STAD (STUDENT TEAM ACHIEVEMENT DIVISIONS) TERHADAPKEMAMPUANMENEMUKAN POKOK-POKOK BERITA YANG DIDENGAR MELALUI REKAMAN BERITA PADA SISWA KELAS VIIISMPSWASTA TUNASHARAPAN KEC. P.BATUTAHUNPEMBELAJARAN 2016/2017
}

\author{
Oleh \\ Eva Catryn Sitohang \\ Drs. Sanggup Barus, M.Pd.
}

\begin{abstract}
ABSTRAK
Penelitian ini bertujuan untuk menjelaskan pengaruh model pembelajaran STAD (Student Team Achievement Divisions) terhadap kemampuan menemukan pokok-pokok berita yang didengar melalui rekaman berita pada siswa kelas VIII SMP Swasta Tunas Harapan Kec.P.Batu tahun pembelajaran 2016/2017.Populasi penelitian ini adalah semua kelas VIII SMP Swasta Tunas Harapan kec. P.Batu sebanyak 147 orang dan pengambilan sampel dilakukan dengan teknik acak kelas, sehingga diperoleh sampel penelitian adalah kelas VIII ${ }^{\mathrm{a}}$ sebanyak 40 orang.Metode yang digunakan dalam penelitian ini adalah metode eksperimen one group pre-test dan post-test design.Instrumen yang digunakan adalah tes menemukan pokok-pokok berita yang didengar melalui rekaman berita. Nilai rata-rata sebelum perlakuan ( $p r e-$ test) adalah 63,12, standar deviasi 11,93, dan standar error 1,91 sedangkan nilai rata-rata setelah perlakuan adalah 76,25, standar deviasi 9,07, dan standar error 1,45. Dengan demikian dapat disimpulkan bahwa nilai rata-rata menemukan pokok-pokok berita yang didengar melalui rekaman berita setelah menggunakan model pembelajaran STAD (Student Team Achievement Divisions)lebih tinggi daripada nilai sebelum menggunakan model pembelajaran STAD (Student Team Achievement Divisions).Sebelum dilakukan pengujian hipotesis terlebih dahulu dilakukan uji persyaratan analisis yaitu uji normalitas dan uji homogenitas. Berdasarkan hasil analisis data diperoleh bahwa data pre-test dan post-test berdistribusi normal dan homogen. Pengujian hipotesis $t_{\text {hitung }}=12,72$ kemudian dikonsultasikan dengan $\mathrm{t}_{\text {tabelpada }}$ taraf signifikasi $5 \%=2,64$. Karena $\mathrm{t}_{\text {hitung }}=12,72>\mathrm{t}_{\text {tabel }}=$ 2,64 maka hipotesis nihil $\left(\mathrm{H}_{0}\right)$ ditolak dan hipotesis alternatif $\left(\mathrm{H}_{\mathrm{a}}\right)$ diterima. Hal ini membuktikan bahwa model pembelajaran STAD (Student Team Achievement Divisions) mempengaruhi kemampuan menemukan pokokpokok berita yang didengar melalui rekaman berita pada siswa kelas VIII SMP Swasta Tunas Harapan Kec. P.Batu tahun pembelajaran 2016/2017.
\end{abstract}

Kata kunci: Pengaruh, Model Pembelajaran STAD, Menemukan, pokokpokok berita yang didengar.

\section{PENDAHULUAN}

Kurikulum Tingkat Satuan Pendidikan (KTSP) pada dasarnya bertujuan mengembangkan kemampuan berbahasa siswa yang ditentukan pada empat aspek 
kemampuan berbahasa yaitu mendengarkan, berbicara, membaca, dan menulis.Keempat aspek tersebut merupakan aspek yang terintegrasi dalam pembelajaran walaupun dalam penyajian di silabus keempat aspek tersebut masih dapat dipisahkan.Kehidupan sehari-hari manusia tidak pernah terlepas dari kegiatan menyimak.Kemampuan menyimak dapat diaplikasikan sebagai pengetahuan yang harus dimiliki oleh seseorang, karena dengan menyimak dapat membantu seseorang dalam menemukan ide, menambah pengetahuan serta menambah informasi.Menyimak bukanlah suatu pekerjaan yang mudah karena dalam proses menyimak, pendengar dituntut untuk memiliki keterampilan menyimak yang memadai." Oleh karena itu pengajaran mendengarkan hendaknya lebih ditingkatkan lagi mengingat pentingnya peranan menyimak dalam meningkatkan pemahaman dan perhatian siswa dalam mendengarkan. Di sini agar pendengar dengan cepat menemukan pokok-pokok berita, alangkah lebih baiknya terlebih dahulu mendengarkan sebuah rekaman berita dan mengetahui cara menemukan pernyataan-pernyataan yang merupakan jawaban dari pokok-pokok berita.Kemampuan untuk menemukan pokok-pokok berita yang didengar mengharuskan agar siswa dapat menemukan pernyataan-pernyataan yang merupakan jawaban dari pokok-pokok berita (apa,siapa, mengapa, dimana, kapan, dan bagaimana) dan dapat menuliskan pokokpokok berita dengan ejaan yang benar.

Salah satu kompetensi dasar mata pelajaran Bahasa Indonesia pada kurikulum tingkat satuan pendidikan yang harus dikuasai oleh siswa tingkat SMP adalah mampu menemukan pokok-pokok berita yang didengar melalui rekaman berita berdasarkan unsur-unsur berita.Menyimak merupakan keterampilan berbahasa yang digunakan untuk menangkap isi atau pesan yang disampaikan dengan penuh pemahaman. Menyimak membutuhkan kemampuan penuh pemahaman dan perhatian serta apresiasi. Kegiatan Menyimak juga bermakna mendengarkan (memperhatikan) baik-baik apa yang diucapkan atau dibaca orang. Shabab (2008 : 21) menyatakanpokok-pokok berita sering disebut dengan unsur-unsur berita, yaitu unsur yang menjadi pembangun dalam sebuah berita. Umumnya sebuah berita berpedoman kepada rumus $5 \mathrm{w}+1 \mathrm{~h}$.Pedoman ini sering juga disebut sebagai syarat kelengkapan sebuah berita. Adapun yang menjadi pokok atau unsur berita yang dikenal dengan $5 \mathrm{w}+1 \mathrm{~h}$ yaitu Who (siapa), What (apa), Where (di mana), When (kapan), Why (mengapa), dan How (bagaimana).Siapa (who) : "siapa" disini bisa berupanama orang atau bukan nama orang (lembaga, instansi, organisasi, kelompok, dan sebagainya).Apa (what) : "apa" digunakan sebagai peristiwa yang ditonjolkan.Kapan (when) : "kapan" berkaitan dengan masalah waktu.Di mana (where) : berkaitan dengan tempat dan lokasi 
kejadian.Mengapa (why) : untuk mengungkap suatu masalah atau peristiwa, di mana penyebab dari peristiwa atau pendapat yang disampaikan mempunyai daya pengaruh yang besar.Bagaimana (how) : bagaimana proses terjadinya (dari awal sampai akhir) suatu peristiwa atau pendapat.

Kenyataan yang terjadi di lapangan kemampuan siswa dalam menemukan pokokpokok berita yang didengar masih rendah. Hasil wawancara peneliti dengan $\mathrm{Bu}$ Lasmaria, S.Pd., yaitu guru bahasa Indonesia kelas VIII SMPNegeri 2 Pancur Batu, menunjukkan bahwa kemampuan siswa dalam menyimak masih kurang memenuhi harapan. Siswa kurang termotivasi atau malas untuk menyimak.Hal ini disebabkan oleh kemauan siswa dalam menyimak yang minim sehinggaapa yang didengarkan kurang disimak.Kemampuan siswa dalam menemukan pokok-pokok berita yang didengar pun masih kurang. Sebagian besar siswa merasa sulit bagaimana cara menemukan pokok-pokok berita yang didengar melalui rekaman berita.

Kurangnya kemampuan siswa dalam menemukan pokok-pokok berita yang didengar melalui rekaman berita juga terbukti dari hasil penelitian yang dilakukan oleh Diana Novita Sianturi (2011:65).Nilai rata-rata siswa menemukan pokok-pokok berita yang didengar melalui rekaman beritasebelum menggunakan model pembelajaran STAD adalah 64 sedangkan setelah menggunakan model pembelajaran STAD, siswa memperoleh nilai ratarata 74.

Selain itu, berdasarkan pengamatan peneliti selama PPL-T di SMK Dharma KaryaBeringin, guru biasanya menyampaikan pembelajaran menyimak dengan metode ceramah yang cenderung monoton. Guru kurang efektif dalam menggunakan model pembelajaran yang sesuai dengan materi untuk menunjang perkembangan hasil belajar siswa. Dalam proses pembelajaran guru lebih menguasai kelas daripada siswa sehingga siswa menjadi merasa tidak ada tuntutan terhadap dirinya untuk lebih aktif dalam proses pembelajaran.

Tidak tepatnya penerapan model pembelajaran oleh guru menyebabkan hasil belajar siswa rendah.Sebaliknya, penerapan model yang tepat dapat diasumsikan memperoleh hasil belajar yang baik. Kurangnya pengetahuan guru terhadap model pembelajaran, tentu saja akan berpengaruh besar terhadap kualitas dari hasil pembelajaran. Tidak dapat dipungkiri bahwa hal ini sering kali terabaikan. Guru merasa tidak perlu memilih model apapun dalam proses pembelajaran yang seharusnya itu merupakan salah satu hal yang penting untuk menunjukkan berhasil tidaknya proses pembelajaran tersebut. 
Salah satu model pembelajaran yang dapat digunakan guru untuk meningkatkan keterampilan menyimak adalah model pembelajaran STAD (Student Team Achievement Divisions).Trianto (2009 : 52), "Model pembelajaran STAD adalah suatu model yang lebih menekankan pada kegiatan belajar kelompok, dimana siswa secara aktif melakukan diskusi, kerja sama membantu, dan semua anggota kelompok mempunyai peran dan tanggung jawab.'Pada proses pembelajaran dengan menggunakan model STAD siswa ditempatkan dalam tim belajar beranggotakan 4-5 orang yang merupakan campuran menurut tingkat prestasi, jenis kelamin dan suku. Guru menyajikan pelajaran dan kemudian siswa bekerja dalam tim mereka memastikan bahwa seluruh anggota tim telah menguasai pelajaran tersebut, diberikan tes tentang materi dan pada saat tes ini mereka tidak diperbolehkan saling membantu.

Model pembelajaran STAD(Student Team Achievement Divisions) cocok untuk menemukan pokok-pokok berita yang didengar melalui rekaman berita karena model ini siswa dilatih menyimak menemukan pokok-pokok yang didengar melalui rekaman berita dalam tim belajar beranggotakan 4-5 orang yang merupakan campuran menurut tingkat prestasi, jenis kelamin dan suku.Siswa tidak akan merasa kesulitan untuk menemukan pokokpokok berita yang mereka dengar.

MenurutImas Kurniasih (2015:22), model pembelajaran STAD (Student Team Achievement Divisions) memiliki kelebihan sebagai berikut.

1. Karena dalam kelompok siswa dituntut untuk aktif sehingga dengan metode ini siswa dengan sendirinya akan percaya diri dan meningkat kecakapan individunya.

2. Interaksi sosial yang terbangun dalam kelompok,dengan sendirinya siswa belajar dalam bersosialisasi dengan lingkungannya (kelompok).

3. Dengan kelompok yang ada, siswa diajarkan untuk membangun komitmen dalam mengembangkan kelompoknya.

4. Mengajarkan menghargai orang lain dan saling percaya.

5. Dalam kelompok siswa diajarkan untuk saling mengerti dengan materi yang ada, sehingga siswa saling memberitahu dan mengurangi sifat kompetitif.

\section{METODE PENELITIAN}

Metode penelitian merupakan cara ilmiah untuk mendapatkan data dengan tujuan dan kegunaan tertentu. Penentuan suatu metode harus disesuaikan dengan tujuan penelitian dan metode penelitian diharapkan dapat menjawab permasalahan yang ada.Adapun metode yang digunakan dalam penelitian ini adalah metode penelitian eksperimen.Metode penelitian eksperimen merupakan metode penelitian yang digunakan untuk melihat pengaruh dari suatu perlakuan.Desain penelitian ini adalah one group pre-test dan post-test design.Pada desain ini 
dilakukan observasi sebanyak dua kali yaitu sebelum eksperimen dan sesudah eksperimen pada satu kelompok/kelas saja tanpa ada kelompok pembanding.Prosedur yang dilakukan dalam penelitian ini ialah pembelajaran yang dimulai dari pre-test untuk mengetahui kemampuan awal siswa dalam menemukan pokok-pokok berita yang didengar melalui rekaman berita. Kemudian, diadakan pembelajaran dengan menggunakan model pembelajaran STAD (Student Team Achievement Divisions) dan dilakukan post-test untuk melihat pengaruh model pembelajaran STAD (Student Team Achievement Divisions)terhadap kemampuan menemukan pokok-pokok berita yang didengar melalui rekaman beritapada siswa kelas VIII SMP Swasta Tunas Harapan Kec. P.Batu tahun pembelajaran 2016/2017.

Data yang diperoleh selanjutnya dianalisis secara statistik dengan langkah-langkah analisis yaitu data hasilpre-test danpost-testdisusun dalam bentuk tabel, menentukan nilai rata-rata dan standar deviasi dari data hasilpre-test danpost-test, menghitung uji normalitas, uji homogenitas, danuji hipotesis. Setelah $t$ diketahui maka nilai tersebut akan dikonsultasikan dengan tabel pada taraf signifikan 5\% dengan derajat kebebasan $(\mathrm{dk})=\mathrm{n}-1$


hipotesis alternatif(Ha) diterima.

\section{HASIL PENELITIAN DAN PEMBAHASAN}

\section{Hasil Penelitian}

a. Kemampuan Menemukan Pokok-pokok Berita yang didengar melalui rekaman berita Sebelum Menggunakan Model Pembelajaran STAD(Student Team Achievement Divisions )

Kemampuan menemukan pokok-pokok berita yang didengar melalui rekaman berita pada siswa kelas VIII SMP Swasta Tunas Harapan Kec. P.Batu tahun pembelajaran 2016/2017berdasarkanunsur-unsur berita sebelum menggunakan model pembelajaran STAD (Student Team Achievement Divisions), menunjukkan nilai rata-rata siswa adalah 63,12, dengan nilai tertinggi adalah 85 dan nilai terendah adalah 45 . Berikut ini rincian nilai siswa pada hasil tes menemukan pokok-pokok berita yang didengar melalui rekaman berita sebelum menggunakan model pembelajaran STAD (Student Team Achievement Divisions) termasuk dalam kategori sangat baik sebanyak 3 orang atau 7,5\%, kategori baik sebanyak 9orang atau 22,5\%, kategori cukup 15 orang atau 37,5\%, kategori kurang sebanyak 8 orang atau $20 \%$ dan sangat kurang 5 orang atau 12,5\%. Identifikasi data di atas cenderung dalam kategori cukup. 


\section{b. Kemampuan Menemukan Pokok-pokok Berita yang didengar melalui rekaman berita SesudahMenggunakan Model Pembelajaran STAD(Student Team Achievement Divisions)}

Kemampuan menemukan pokok-pokok berita yang didengar melalui rekaman berita pada siswa kelas VIII SMP Swasta Tunas Harapan Kec. P.Batu tahun pembelajaran 2016/2017 berdasarkan unsur-unsur berita sesudah menggunakan model pembelajaran STAD (Student Team Achievement Divisions), menunjukkan nilai rata-rata siswa adalah 76,25 , dengan nilai tertinggi adalah 90 dan nilai terendah adalah 60 . Berikut ini rincian nilai siswa pada hasil tes menemukan pokok-pokok berita yang didengar melalui rekaman berita sesudah menggunakan model pembelajaran STAD (Student Team Achievement Divisions) termasuk dalam kategori sangat baik sebanyak 11 orang atau 27,5\%, kategori baik sebanyak 21 orang atau 52,5\%, kategori cukup 8 orang atau $20 \%$, kategori kurang sebanyak tidak ada atau $0 \%$, dan sangat kurang tidak ada atau $0 \%$. Identifikasi data di atas cenderung dalam kategoribaik.

\section{c. Pengaruh Model Pembelajaran STAD (Student Team Achievement Divisions) Terhadap Kemampuan Menemukan Pokok-pokok Berita yang didengar melalui rekaman berita}

Berdasarkan uji analisis dan normalitas dari data pre-test dan post-test yang diperoleh siswa merupakan data yang berdistribusi normal. Hal ini dapat dilihat dari uji normalitas hasil

pre-test, yaitu $L_{\text {hitung }}<L_{\text {tabel }}(0,11<0,14)$ dan uji normalitas hasil post-testyaitu $L_{\text {hitung }}<$ $L_{\text {tabel }}(0,085<0,14)$. Dari uji homogenitas juga terbukti bahwa sampel dalam penilitian ini berasal dari populasi yang homogen, nilai homogenitas yaitu, $F_{\text {hitung }}<F_{\text {tabel }}$ yakni $1,73<1,74$.

Setelah data terbukti normal dan homogen maka uji hipotesis dapat dilakukan.Dari pengujian hipotesis yang dilakukan diperoleh $t_{o}>t_{\text {tabel }}$, yakni 12,72>2,64 telah membuktikan bahwa hipotesis alternatif (Ha) diterima. Dengan demikian, dapat dinyatakan bahwa model pembelajaran STAD (Student Team Achievement Divisions) memiliki pengaruh yang signifikan terhadap kemampuan menemukan pokok-pokok berita yang didengar melalui rekaman berita pada siswa kelas VIII SMP Swasta Tunas Harapan Kec. P.Batu tahun pembelajaran 2016/2017.

\section{Pembahasan Hasil Penelitian}

Kemampuan menemukan pokok-pokok berita yang didengar melalui rekaman berita sebelum menggunakan model pembelajaran STAD dilakukan melalui proses pembelajaran secara langsung. Hal ini sesuai dengan pendapat Dansereau (dalam Asmani, 2014:41) bahwa 
pembelajaran dilakukan secara langsung atau lisan dan berganti dengan tujuan menyampaikan bagian-bagian materi yang dipelajari.

Hasil penelitian yang telah dilakukan oleh Diana Novita Sianturi (2011:65) dengan menggunakan model STAD skor yang diperoleh daripre-test dan post-testdalam menulis teks berita mengalami peningkatan karena siswa semakin termotivasi, aktif, dan terampil dengan adanya model baru yang diterapkan dalam kelas mereka. Nilai rata-rata pretest yang diproleh 64 sedangkan nilai rata-rata postest yang diperoleh 74. Untuk itu, model STAD sangat berpengaruh positif terhadap meningkatkan kemampuan siswa menulis teks berita.

Berdasarkan data yang telah terkumpul dinyatakan bahwa kemampuan menemukan pokok-pokok berita yang didengar melalui rekaman berita sebelum menggunakan model pembelajaran STAD tergolong kategori cukup dengan nilai rata-rata 63,12. Siswa yang mendapat nilai sangat baik sebanyak 3 orang atau 7,5\%, nilai berkategori baik sebanyak 9 orang atau $22,5 \%$, nilai cukup sebanyak 15 orang atau $37,5 \%$, nilai kurang sebanyak 8 orang atau $20 \%$, dan nilai sangat kurang sebanyak 5 orang atau $12,5 \%$. Hasil nilai kecenderungan tersebut menunjukkan bahwa, kemampuan menemukan pokok-pokok berita yang didengar melalui rekaman berita sebelum menggunakan model pembelajaran STAD termasuk dalam kategori cukup.

Model pembelajaran yang tidak tepat digunakan oleh guru akan menyebabkan siswa kurang termotivasi, kurang berniat dalam proses belajar mengajar terkhusus dalam kegiatan menemukan pokok-pokok berita yang didengar melalui rekaman berita tepatnya dalam kegiatan menyimak siswa akan mengalami kesulitan. Siswa kurang aktif dalam belajar apabila guru hanya menggunakan model pembelajaran yang kurang tepat atau hanya menggunakan metode ceramah. Siswa akan hanya mengingat penjelasan guru dalam waktu singkat apabila tidak langsung melibatkan siswa dalam kegiatan menyimak tersebut. Siswa cenderung tidak mengetahui hal apa yang hendak ditemukan dari rekaman berita dan bagaimana cara menemukan pokok-pokok berita dari rekaman tersebut. Siswa harus dibimbing untuk menggali pengetahuan menyimak berdasarkan pengalaman mereka dalam menemukan pokok-pokok berita yang didengar sehingga merekapun menganggap pembelajaran itu bermakna dan tidak monoton.

Setelah melakukan prosedur penelitian seperti melakukan analisis data dan melakukan pengujian hipotesis, penggunaan model pembelajaran STAD (Student Team AchievementDivisions) dalam kegiatan menemukan pokok-pokok berita yang didengar 
melalui rekaman berita pada siswa kelas VIII SMP Swasta Tunas Harapan Kec.P.Batu Tahun Pembelajaran 2016/2017 ternyata berpengaruh. Hal ini terbukti dari hasil penelitian yang menunjukkan nilai siswa menemukan apa, siapa, dimana, mengapa, bagaimana, dan kapan peristiwa dalam berita itu terjadi yang didengar melalui rekaman berita mengalami peningkatan. Nilai rata-rata siswa sesudah menggunakan model pembelajaran STAD yaitu sebesar 76,25. Siswa yang mendapat nilai yang termasuk kategori sangat baik sebanyak 11 orang atau $27,5 \%$, nilai baik sebanyak 21 orang atau 52,5\%, dan nilai cukup sebanyak 8 orang atau 20\%. Nilai kecenderungan menunjukkan bahwa kemampuan siswa dalam menemukan apa, siapa, dimana, mengapa, bagaimana, dan kapan peristiwa dalam berita itu terjadi yang didengar melalui rekaman berita tergolong kategori baik.

Peningkatan nilai yang diperoleh siswa disebabkan model pembelajaran STAD (Student Team Achievement Divisions). Pada model pembelajaran ini, yang diutamakan ialah sikap keaktifan dalam menemukan pokok-pokok berita yang didengar melalui rekaman berita berdasarkan latihan-latihan dalam tim belajar untuk melatih kemampuan menyimak dan dapat memotivasi siswa dalam belajar siswa. Melalui kegiatan yang diawali siswa dengan berdiskusi dalam tim belajar, memahami cara menemukan pokok-pokok berita yang didengar, menjawab soal-soal latihan tentang menemukan apa, siapa, dimana, mengapa, bagaimana, dan kapan peristiwa dalam berita itu terjadi yang didengar melalui rekaman berita baik secara individual maupun kelompok, mempresentasikan perwakilan tiap tim belajar, dan menerima pemberian penghargaan kelompok, maka pokok-pokok berita dapat ditemukan melalui rekaman berita dengan baik. Dalam kegiatan menemukan pokok-pokok berita yang didengar melalui rekaman berita, berdasarkan model tersebut siswa akan cenderung dilatih dalam kemampuan menyimak yang terkandung dalam rekaman berita sehingga siswa lebih mudah menemukan pokok-pokok berita yang didengar melalui rekaman berita tersebut. Model pembelajaran STAD ini sangat tepat digunakan menemukan pokok-pokok berita yang didengar melalui rekaman berita yang cenderung membutuhkan pemahaman.

Berdasarkan hasil yang diperoleh daripre-test dan post-testdalam menemukan pokokpokok berita yang didengar melalui rekaman berita mengalami peningkatan nilai setiap siswa. Dari indikator kemampuan menemukan pokok-pokok berita yang didengar melalui rekaman berita, terlihat bahwa perolehan nilai siswa sesudah menggunakan model pembelajaran STAD lebih baik dibandingkan sebelum menggunakan model pembelajaran STAD. Hal tersebut dapat dilihat dari nilai rata-rata siswa, standar deviasi, dan standar error yang mengalami peningkatan setelah menggunakan model pembelajaran STAD tersebut. 
Berdasarkan aspek penilaian menemukan pokok-pokok berita yang didengar melalui rekaman berita, yang menjadi kriteria penilaian adalah apa, siapa, dimana, mengapa, bagaimana, dan kapan peristiwa dalam berita itu terjadi. Akhirnya, peneliti menyimpulkan bahwa kemampuan siswa menemukan pokok-pokok berita yang didengar melalui rekaman berita setelah menerapkan model pembelajaran STAD sangat berpengaruh dibandingkan kemampuan siswa sebelum menggunakan model pembelajaran tersebut.

\section{PENUTUP}

Berdasarkan hasil penelitian yang telah diuraikan pada pembahasan, maka diperoleh simpulan, yaitu kemampuanmenemukan pokok-pokok berita yang didengar melalui rekaman berita pada siswa kelas VIII SMP Swasta Tunas Harapan Kec. P.Batu tahun pembelajaran 2016/2017 sebelum menggunakan model pembelajaran STAD (Student Team Achievement Divisions) memiliki nilai rata-rata 63,12 dan berkategori cukup.Kemampuan menemukan pokok-pokok berita yang didengar melalui rekaman berita pada siswa kelas VIII SMP Swasta Tunas Harapan Kec. P.Batu tahun pembelajaran 2016/2017 sesudah menggunakan model pembelajaran STAD (Student Team Achievement Divisions) memiliki nilai rata-rata 76,25 dan berkategoribaik.Penggunaan model pembelajaran STAD (Student Team Achievement Divisions)berpengaruh terhadap kemampuan menemukan pokok-pokok berita yang didengar melalui rekaman beritapada siswa kelas VIII SMP Swasta Tunas Harapan Kec. P.Batu tahun pembelajaran 2016/2017. Hal ini dapat dilihat dari hasil pengujian hipotesis yaitu $t_{o}>t_{\text {tabel, }}$

yakni 12,72> 2,64 yang membuktikan hipotesis alternatif $\left(\mathrm{H}_{\mathrm{a}}\right)$ diterima dan hipotesis nihil $\left(\mathrm{H}_{0}\right)$ ditolak.

\section{DAFTAR PUSTAKA}

Arikunto, Suharsimi. 2010. Prosedur Penelitian Suatu Pendekatan Praktik. Jakarta: Rineka Cipta.

Barus, Sedia Willing. 2010. Jurnalistik Petunjuk Teknis Menulis Berita. Jakarta: PT Gelora Aksara Pratama.

Isjoni. 2009. Pembelajaran Kooperatif. Yogyakarta: Pustaka Pelajar.

Kurniasih, Imas. 2015. Ragam Pengembangan Model Pembelajaran untuk Peningkatan Profesionalitas Guru. Yogyakarta: Kata Pena.

Shabab. 2008. Cara Mudah Menjadi Jurnalis. Jakarta: Diwan Publishing

Tarigan. 1986. Menyimak Sebagai Suatu Keterampilan Berbahasa. Bandung: Angkasa. 
Trianto. 2011. Mendesain Model Pembelajaran Inovatif-Progresif: Konsep, Landasan, dan Implementasinya pada Kurikulum Tingkat Satuan Pendidikan (KTSP). Bandung: Kencana Prenada Media Group.

Sianturi, Diana Novita 2011. Pengaruh Metode Student Team Achievement Divisions (STAD) terhadap Kemampuan Menulis Teks Berita oleh Siswa Kelas VIII SMP Negeri 5 Pematang Siantar Tahun Pembelajaran 2011/2012. Skripsi, Pendidikan Bahasa dan Sastra Indonesia, Medan: Universitas Negeri Medan.

Suharyadi.2013. Peningkatan Kemampuan Menyimak Berita dengan Media Audio dan Model Pembelajaran Stratta Pada Siswa kelas VIII SMPN 13 Purworejo. Skripsi, Pendidikan Bahasa dan Sastra Indonesia, Purworejo: Universitas Muhammadiyah Purworejo. 